Leadership: Jurnal mahasiswa manajemen Pendidikan Islam

ISSN (P): 2721-7108, ISSN (E): 2715-0399

DOI : http://dx.doi.org/10.32478/leadership. v2i2.816

Article Type : Original Research Article

\title{
MANAJEMEN PENINGKATAN EKONOMI MASYARAKAT MELALUI BUDIDAYA KERANG HIJAU DALAM PRESPEKTIF MAQOSID SYARIAH
}

\author{
Muhammad Syauqillah \\ STAI Ma'had Aly Al-Hikam Malang, Indonesia
}

Corresponding author: syauqillahmuhammad@gmail.com

Copyright @ 2021 Author

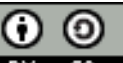

This work is licensed under a Creative Commons Attribution-ShareAlike 4.0

\begin{abstract}
.
The economic management of the majority Campurejo village society relies on shellfish aquaculture. They implement shellfish rearing business practice by installing bamboo into the sea in order to catch the shell easier. Shellfish aquaculture is considered as a very promising occupation because it is highly profitable. Campurejo people formerly are categorized as a lower-middle economic society. Phenomenological approach is used as the research method in this study. Moreover, this research uses empirical data with primary data taken from in-depth interviews with several parties which are involved in green shellfish aquaculture activities and the secondary data obtained from many references related to maqashid syariah and others. The data collection techniques using interviews, observation and documentation. In the data analysis aspect, it is through the stages of data reduction, data presentation, verification and conclusion. The author then uses a data triangulation method in order to test the validity of the data. The results shows good economic management in green shellfish aquaculture will lead to profit which has increased the community's economy and at the same time has a chain effect on the economy in terms of education, health, religiosity and child upbringing. The benefits of shellfish aquaculture aside from providing special impacts, also provide general impacts by opening up jobs and helping the underprivileged people. The variety benefits of green shellfish aquaculture has relevance to the spirit of the sharia which intends to prosper the community. Looking at the aquaculture process and the results associated with the implementation of maqasid syariah through the media of maslahah mursalah, it has been in accordance with the implementation requirements. Along these lines, green shellfish aquaculture is a business practice that is actually accommodated in the unwritten scope of sharia.
\end{abstract}

Keywords: Economic Management, Welfare, Maqashid Syariah 
Leadership: Jurnal mahasiswa manajemen pendidikan Islam

ISSN (P): 2721-7108, ISSN (E): 2715-0399

Vol. 2 No. 2 bulan Juni 2021

\begin{abstract}
Abstrak
Manajemen perekonomian masyarakat Desa Campurejo mayoritas menggantungkan penghasilannya melalui budidaya kerang berupa Praktek usaha pemeliharaan kerang dengan menancapkan bambu di laut. Budidaya kerang sangat menjanjikan karena profit yang diperoleh begitu besar. Masyarakat Campurejo semula adalah masyarakat dengan ekonomi menengah ke bawah. Metode penelitian yang digunakan dalam kajian ini adalah menggunakan pendekatan fenomenologi. Penelitian ini bersifat empiris dengan sumber data primer berupa wawancara dengan pihak yang berkecimpung dalam kegiatan budiaya karang hijau. Adapun data sekundernya adalah informasi yang berikaitan dengan maqasid syariah dan lainnya. Teknik pengumpulan data menggunakan wawancara, observasi dan dokumentasi. Analisis data melalui tahapan reduksi data, penyajian data, verifikasi dan kesimpulan. Guna menguji keabsahan data peneliti menggunakan metode triangulasi data. Hasil pembahasan dengan manajemen perekonomian yang bagus maka profit yang dihasilkan melalui budidaya kerang hijau telah meningkatkan ekonomi masyarakat yang sekaligus memberikan efek berantai terhadap perekonomian dari segi pendidikan, kesehatan, religiusitas dan pola asuh anak. Kemaslahatan budidaya kerang di samping memberikan efek khusus juga memberikan efek umum dengan membuka lapangan pekerjaan dan membantu masyarakat kurang mampu. Variasi maslahat budidaya kerang hijau memiliki relevansi dengan semangat syariat yang bermaksud mensejahterakan masyarakatnya. Menilik proses budidaya serta hasilnya dengan dikaitkan implementasi maqasid syariah melalui media maslahah mursalah telah sesusai dengan syarat implementasinya. Secara garis besar budidaya kerang hijau adalah sebuah praktek usaha yang sebenarnya terakomodir dalam lingkup syariah secara tidak tertulis.
\end{abstract}

Keywords. Manajemen Ekonomi, Kesejahteraan, Maqosid Syariah

\title{
A. PENDAHULUAN
}

Seiring dengan perkembangan zaman, perekonominan dunia semakin menunut manusia untuk bersaing supaya bisa bertahan hidup dengan pendapatan yang maksimal. Banyak cara yang dilakukan oleh manusia mulai dari pekerjaan pabrik,kantor dan bahkan tidak banyak yang mengangkat potensi alam demi mendapatkan uang. Karena itu perlu manajemen perekonomian yang baik mulai dari merencanakan, melakukan bahkan melakukan evaluasi terhadap tindakan ekonomi yang dilakukan oleh masyarakat.

Indonesia memiliki potensi kelautan dan perikanan yang cukup besar Salah satu provinsi adalah Provinsi Jawa Timur yang memiliki luas perairan sebesar 208.338 KM, yang mana meliputi Selat Madura, Laut Jawa, Selat Bali dan Samudera Indonesia dengan panjang garis pantai $1.600 \mathrm{~km} .{ }^{1}$ Salah satu yang memiliki potensi sumber daya kelautan dan perikanan terbesar dan di dalam Jawa Timur ada satu kabupaten yang memiliki potensi alam yang luar biasa yaitu Kabupaten Gresik, tepatnya adalah Desa Campurejo Kecamatan Panceng.

\footnotetext{
${ }^{1}$ Adhinda Dewi Agustine dkk. Pengembangan Sektor Kelautan Dan Perikanan Untuk Meningkatkan Pendapatan Asli Daerah. Jurnal Administrasi Publik (JAP), Vol. 2, No.2. 2014. Hal. 276-280.
} 
Leadership: Jurnal mahasiswa manajemen pendidikan Islam

ISSN (P): 2721-7108, ISSN (E): 2715-0399

Vol. 2 No. 2 bulan Juni 2021

Potensi kekayaan alam di pesisir Indonesia ini sangat banyak, baik dari budidaya tambak maupun laut perikananya. Karena Indonesia merupakan salah satu negara yang memiliki garis pantai 3 terpanjang di dunia, sehingga potensi tambaknya dan perikanan akan jauh lebih besar. Secara tidak langsung potensi perekonomian juga cukup tinggi asalkan masyarakat bisa memanfaatkan sumber daya alam dengan maksimal, maka akan berdampak positif bagi masyarakat sekitar.

Gresik mempunyai keanekaragaman ekosistem yang menyimpan banyak potensi terutama potensi sumber daya perikanan dan kelautan sekalipun banyak industri yang berada di Kota Gresik namun rata-rata masyarakat Desa Campurejo yang terdiri dari 4 Dusun (Sidorejo, Karang tumpuk, Campurejo dan Mojosari) rata-rata penduduk lebih memilih bekerja dengan memanfaatkan alam sekitar dengan bertani, beternak, wiraswasta dan perlautan yang paling banyak di lakukan masyarakat desa sekitar karena 4 dusun ini semua letak posisinya berada di pinggir pantai Utara, Mayoritas kegitan yang dilakukan warga di sana adalah memanfaatkan kekayaan alam yang berada di laut, yakni melakukan budidaya kerang hijau,salah satu perkataan (Zaki 26 Tahun) seorang pembudidaya kerang: "Saya lebih baik bekerja budidaya kerang hijau mas dari pada buruh pabrik, keuntunganya lebih besar"

Maksud dari perkataan Zaki adalah lebih baik kita bekerja di laut dengan melakukan budidaya kerang karena hasil dari budidaya lebih menjanjikan dari pada bekerja di industri, Padahal Upah Minimum Kerja (UMK) yang berada dikabupaten Gresik terbilang cukup tinggi yaitu: Rp. Rp3.580.370,644. ${ }^{2}$

Berdasarkan survei awal yang di lakukan oleh peneliti untuk memperoleh informasi awal dari para budidaya kerang hijau.7 Menurut Rudi (24 tahun) hasil dari budidaya kerang hijau sangat menjanjikan karena hampir tiap panen sekurang kurangnya omset per tempat 20 juta lebih itu belum di berdayakan dengan hasil penangkapan ikan di sekitar tempat budidaya kerang hijau yang tiap hari juga sekurang kurang 150 ribu bersihnya. Sedangkan rudi memiliki 3-4 tempat tergantung musim, dia memiliki kurang lebih 23 karyawan.

Bapak nurhuda berbeda dengan yang lain karena beliau tidak murni sebagai pembudidaya kerang hijau namun bapak Nur Huda ini seorang guru dan untuk budidaya kerang hijaunya, dia menyuruh orang untuk ikut membantu proses penanaman hingga pada masa panen sehingga nanti diterapakan sistem bagi hasil. Dari beberapa pemaparan di atas ketika di sajikan dan dibantu beberapa tetangga yang menjadi karyawanya sejumlah 18 Orang.

Melihat potret tentang kehidupan masyarkat Desa Campurejo yang terbilang sejahtera merupakan faktor utama ini juga sesuai dengan tujuan pembangunan ekonomi sesuai dengan beberapa pendapat ahli teori struktural menurut Hadi Priyono dalam Femy M.G. Tulusan dan Very Y. Londa strategi perkembangan negara Indonesia yang berkembang seperti ini adalah penciptaan lapangan kerja, memenuhi kebutuhan pokok, pengembangan sumber daya alam, sumber daya manusia dan mengutamakan sektor ekonomi nasional. ${ }^{3}$

Hal tersebut tentunya akan berkaitan dengan usaha peningkatan kesejahteraan ekonomi masyarakat. Dalam hal ini, jika berbicara mengenai kesejahteraan maka akan berkaitan dengan usaha atau kemampuan keluarga untuk memenuhi semua kebutuhan hidup

\footnotetext{
${ }^{2}$ Detiknews pada Tanggal 22 Desember 2020 Jam 18.55 WIB

${ }^{3}$ Femy M. G. Tulusan dan Very Y. Londa Peningkatan Pembangunan ekonomi melaluhi pemberdayaan desa. (Jurnal LPPM Bidang EkoSosBudKum Volume 1 Nomor 1 Tahun 2014) (Fakultas Ilmu Sosial dan Pemerintahan, Universitas Sam Ratulangi).
} 
Leadership: Jurnal mahasiswa manajemen pendidikan Islam

ISSN (P): 2721-7108, ISSN (E): 2715-0399

Vol. 2 No. 2 bulan Juni 2021

yang layak dan produktif. ${ }^{4}$ Secara mendasar Al-Qur'an telah menyebutkan tiga macam kebutuhan dasar manusia yaitu kebutuhan sandang, pangan dan papan yang keseluruhannya harus dicapai dengan usaha dan kerja keras. ${ }^{5}$

Kebutuhan inilah yang akan mendorong manusia melakukan pengelolahan perekonomian dalam kehidupan dalam salah satunya melalui usaha pembudidayaan yang dilakukan. Kesejahteraan dapat diperoleh dengan usaha untuk meningkatkan ekonomi masyarakat melalui suatu proses untuk peningkatan kemampuan masyarakat untuk memanfaatkan sunberdaya yang dimiliki dan yang tersedia di lingkungan sekitarnya.

Di Desa Campurejo penduduknya semua muslim sedangkan model kegiatan perekonomian yang di lakukan sekarang menganut ilmu barat, akibat pengaruh faktor dan arus globalisasi dan juga budaya serta kultur barat yang bisa mempengaruhi jiwa masyarakat serta gaya perekonomian mereka lebih cencerung instan atau menggunakan barang langsung jadi dan jarang memanfaatkan potensi alam, seharusnya karena penduduknya muslim harusnya bisa menerapkan prinsip-prinsip ekonomi islam seperti Maqoșid Syariah. Maqoșid Syariah atau tujuan akhir ilmu fiqih merupakan usaha mencapai keridhoan Allah SWT dengan melaksanakan syariahnya di muka bumi ini, sebagai pedoman hidup individual, hidup berkeluarga maupun hidup bermasyarakat.

Menurut Ali dan Rahmalani di dunia Barat tidak serta merta akan menghasilkan kesuksesan yang sama akibat perbedaan nilai-nilai, kultur- budaya, ideologi dan pandangan hidup yang berbeda yang dimiliki oleh masyarakat muslim. Negara-negara Islam seharusnya mendisain model pembangunan ekonominya berdasarkan pada ajaran Islam. ${ }^{6}$

Dari beberapa pernyataan diatas peneliti tertarik untuk meneliti fenomena yang ada karena. Berbagai macam fenomena potensi alam ketika di manajemen dengan baik maka dapat meningkatkan pendapatan ekonomi masyarakat, dan di Desa Campurejo ini potensi kegiatan ekonomi sangat meningkat terutama pada daerah pesisir. Karena kegitan dari hasil budidaya kerang bukan hanya keuntungan penjualan tapi dari berbagai proses kegitan tersebut hingga hasil panen dan penjulan bisa membuka lapangan pekerjaan bagi warga sekitar dan masyarakat bisa merasakan keuntungan untuk memenuhi keberlansgungan hidup masyarkat sekita

\section{B. METODE PENELITIAN}

Menurut Burhan Bugin Dalam pelaksanan penelitian ini menggunakan pendekatan fenomenologi sebagai bagian dari penelitian kualitatif dengan ciri, karakter, sifat, model, tanda, atau gambaran tentang kondisi, situasi ataupun fenomena tertentu. Lokasi penelitian berada di Desa Campurejo Kecamatan Panceng Kabupaten Gresik, Subjek penelitian untuk mencari masalah penelitian lebih di kenal dengan informan yaitu orang yang di Manfaatkan untuk memberikan informasi tentang situasi dan kondisi latar penelitian. ${ }^{7}$

\footnotetext{
${ }^{4}$ Hartoyo dan Noorma Bunga Aniri, Analisis Tingkat Kesejahteraan Keluarga Pembudidaya Ikan dan Non Pembudi Daya Ikan di Kabupaten Bogor, Jurnal Ilm. Kel dan Kons,(1 Januari 2010)

${ }^{5}$ Zaki Fuad Chalil, Pemerataan Distribusi Kekayaan Dalam Ekonomi Islam, (Jakarta: Erlangga, 2009). h. 110 .

${ }^{6}$ Ali Rama Dan Makhlan, Pembangunan Ekonomi Dalam Tinjauan Maqashid Syari'ah (Dialog Vol. 36, No.1, Agustus 2013).

${ }^{7}$ Burhan Bugin, Penelitian Kualitatif Komunikasi Ekonomi, Kebijakan Public dan Ilmu Sosial Lainnya. Jakarta: Kanacan Media Group, 2007. Hlm 68.
} 
Leadership: Jurnal mahasiswa manajemen pendidikan Islam

ISSN (P): 2721-7108, ISSN (E): 2715-0399

Vol. 2 No. 2 bulan Juni 2021

Menurut Sugiono Data Penelitian ini dibagi menjadi dua yaitu sumber data primer dan sumber data sekunder. Sumber data primer adalah sumber yang langsung memberikan data kepada pengumpul data, dan sumber data sekunder merupakan sumber yang tidak langsung memberikan data kepada pengumpul data. ${ }^{8}$

Dalam penelitian ini untuk memperoleh data dalam hal ini ada beberapa metode yang akan di lakukan wawancara, observasi dan dokumentasi. Berdasarkan uraian metode pendekatan dan jenis penelitian di atas yang digunakan dalam penelitian ini adalah penelitian kualitatif, maka peneliti akan melakukan teknik analisis data dengan cara kualitatif juga misalnya sejak sebelum memasuki dilapangan, selama dilapangan, dan setelah dilapangan.

Proses analisis data secara fenomenologis dalam penelitian ini berdasarkan teknik fenomenologi transendental. Berikut ini adalah tahap-tahap teknik analisis data penelitian secara fenomenologis Noema, Noesis dan Ephoche (Bracketing).

\section{HASIL DAN PEMBAHASAN}

Para petani tambak kerang hijau terdiri dari kalangan Muda dan tua menurut pak Aminuddin Kepala Desa mengatakan bahwa "pemilik kerang hijau atau pembudidaya rata-rata bervariasi jumlah tiap penduduk di dusun masing-masing selama ini belum ada yang mendata dari pihak kelurahan sendiri, terkadang dari 3 tempat budidaya itu bisa menjadi lahan pencarian untuk dua keluarga, ada yang satu orang juga mempunyai 2 tempat bahkan lebih begitu kata pak aminuddin selaku Kepada Desa". ${ }^{9}$

Hasil penelitian dari pembudidaya kerang hijau yang di lakukan di Desa Campurejo, akan paparkan hasil dari beberapa wawancara yang di lakukan oleh peneliti:

"kata Mbah Jalil budidaya kerang hijau ini sudah ada semenjak dulu waktu saya kecil sudah ada tapi sebagian kecil masyarkat yang melakukan budidaya kerang hijau karena dulu masyarakat sudah bisa mencukupi kebutuhan hidupnya dengan memancing ikan dan menangkap ikan dengan njolo atau menjaring ikan sesuai dengan kebutuhan saya, dan rata-rata kehidupan masyakat di desa campurejo terbilang masih susah unutk mencari pekerjaan banyak yang menjadi TKI di malasyia demi memenuhi kebutuhan hidup keluarganya bahkan sekolah belum begitu di pikirkan oleh orang tua. ${ }^{10}$

Melihat Cerita Mbah jalil potret masyakat Desa Campurejo dulu sebelum Budidaya Kerang Hijau itu maju pesat dan diminati banyak masyarakat kehidupan mereka hanya mendekati Pra sejahtera karena minimnya pendapatan perkonomian di keluarga mereka tapi setelah masyarakat mulai banyak menggeluti budidaya kerang hijau hingga saat ini maka kata mbah jalil ketika di wawancarai peneliti masyarakat sekarang yang melakukan pembudidaya kerang sekang sudah banyak sukses dan kehidupanya mapan dengan pengasilan yang di miliki saat ini ada yang tetap biasa-biasa sja tapi tidak kekurangan ada yang kehidupanya berubah drastis bermacam macam rata-rata pemanfatan alam dari budidaya kerang sangat menjanjikan.

Setelah masyakat melakukan budidaya kerang hijau hingga saat ini banyak hal yang di temukan peneliti jika di lihat dari manfaat budidaya kerang hijau dilihat dari bebrapa sudut pandang diantaranya:

\footnotetext{
${ }^{8}$ Sugiyono, Metode Penelitian Kuantitatif Kualitatif dan R\&D (Bandung: Alfabeta, 2006), hlm. 276-284.

${ }^{9}$ Aminuddin Aziz (Wawancara kepala Desa) di kantor Desa pada Tanggal 15 Mei 2019

${ }^{10}$ Mbah Jalil adalah seorang Pembudidaya yang sudah lansia dan tidak bekerja lagi, dulu beliau kata bebrapa warga beliau yang paling sukses budidaya kerang hijau di Masanya. (Wawancara )di rumah Tanggal 14 April 2019
} 
Leadership: Jurnal mahasiswa manajemen pendidikan Islam

ISSN (P): 2721-7108, ISSN (E): 2715-0399

Vol. 2 No. 2 bulan Juni 2021

\section{Manfaat Budidaya dari segi Ekonomi}

Manusia hidup membutuhkan perkonomian yang cukup untuk memenuhi kebutuhan hidupnya, dengan cara bekerja dan memanfaatkan kekayaan alam yang sudah di sediakan Allah SWT untuk umat manusia hidup di dunia, para pembudiaya, beberapa informan mengaku kehidupan mereka tercukupi ketika melakukan budidaya kerang hijau, mereka bisa membeli kebutuhan sehari-hari dengan penghasilan yang didapatkan dari budidaya kerang hijau. Seperti yang diungkapkan oleh bapak Romaji yang diwawancarai peneliti pasar ketika sedang menjual kerangnya di pasar.

"Alhamdulillah mas...perkonomian keluraga saya terkukupi semua kebutuhanya, saya dan kelurga bisa makan ayam terkadang juga ikan hasil tangkapan di tempat budidaya, kalau dipikir-pikir semua kebutuhan saya terpenuhi"11

Hal yang sama juga diungkapkan oleh bapak samui'in yang diwawancarai di tempat bengkel pembuatan dan perbaikan perahu:

"saya dulu berawal dari keluraga yang kurang mampu mas dalam segi perkonomian banyak usaha yang saya jalankan termasuk membuka toko tapi hasilnya tidak sesuai untuk mneutupi kbutuhan saya, akahirnya saya menggeluti usaha budidaya kerang yang di laut akhirnya kebutuhan saya mulai bisa terpenuhi, kemudian hasil saya kumpulkan tiap panenya untuk membeli sepeda motor, membeli perahu sendiri tapi dengan nyicil setelah bertahun tahun saya juga membuka bengkel perahu untuk alat transportasi budidaya kerang hijau ke laut"12

Lapangan pekerjaan bisa bertambah dengan adanya budidaya kerang hijau dari segi usaha kerangnya sendiri juga beberapa alat pendukungnya seperti pak samu'in yang mebuka lapangan pekerjaan baru di bengkel perahu. Dalam melakukan manajemen perekonomian sudah sangat bagus sekali, karena dari segi pemanfaatan hasil alam bisa menghasilkan pendapatan dan juga dapat membuka lapangan pekerjaan ini membuktikan bahwa manajemen jika di jalankan dengan baik maka akan maksimal profit yang didapatkan.

2. Manfaat Budidaya dari segi pendidikan

Dengan pendidikan, manusia akan menjadi makhluk yang beradab dan berbudi pekerti yang luhur. Meningkatnya mutu pendidikan maka produktivitas manusia dimasa yang akan datang juga akan meningkat, hal ini bisa dibuktikan dengan kemampuan manusia terhadap iptek yang pada saat ini menjadi sebuah tren, oleh karena itu sebgai orang tua kita harus mempersiapkan pendidikan anak se Dini mungkin, Dari ke beberapa Informan ada 1 informan yang tidak memiliki anak namun mempunyai tanggungan untuk membiayai pendidikan dia sampai dewasa nanti. Rata-Rata anak para pembudidaya kerang hijau minimal pendidikanya SMA - Sarjana.

Seperti yang diungkapkan oleh bapak Romaji yang diwawancarai peneliti di pasar ketika sedang menjual kerangnya di pasar:

"Anak saya saya sekolahkan semuanya mas...dengan biaya sendiri yang pertama (leli) kuliah mendapatkan Beasiswa Santri karena dulu pernah mondok waktu SMA yang ke tiga masih ada di SMA 1 anak Yang 2 di SMP saya punya cita-cita semua anak saya harus menjadi Sarjana semuanya"13 senada dengan bapak Romaji keterangan dari bapak samuin:"Saya memiliki empat anak. tiga diantaranya telah saya kuliahkan dan satu masih sedang kuliah di Surabaya. saya dulu khawatir tidak bisa menyekolahkan anak tinggi-tinggi, karena

\footnotetext{
${ }^{11}$ Romaji, Wawancara (Pasar Desa Campurejo) Tempat Pelelangan Ikan (TPI) 25 April 2019

${ }^{12}$ Samu'in Wawancara (Bengkel Perahu) 23 April 2019

${ }^{13}$ Romaji, Wawancara (Pasar Desa Campurejo) Tempat Pelelangan Ikan (TPI) 25 April 2019
} 
Leadership: Jurnal mahasiswa manajemen pendidikan Islam

ISSN (P): 2721-7108, ISSN (E): 2715-0399

Vol. 2 No. 2 bulan Juni 2021

keterbatasan biaya. kini syukur al-hamdulillah saya bisa memberikan pendidikan cukup buat bekal anak saya". ${ }^{14}$

Berdasarkan wawancara di atas, dapat dipahami bahwa kesempatan memberi pendidikan kepada putra putri masyarakat Campurejo dapat dilakukan setelah mapannya ekonomi dari budidaya karang hijau. banyak dari mereka menyekolahkan anak hingga ke perguruan tinggi. di samping itu budidaya ini merupakan pembelajaran penting tentang bagaimana cara meningkatkan mutu taraf hidup ekonomi seseorang. masyarakat yang terjun dalam usaha budidaya karang hijau semakin mengerti tentang pentingya pembelajaran peningkatan ekonomi. di samping itu wawasan inin juga ditularkan kepada orang lain.

3. Manfaat Budidaya dari segi Religiusitas

Islam menjadi satu-satunya agama yang dipeluk oleh masyarakat Campurejo. kepatuhan masyarakat terhadap syariat islam sangat variatif berdasarkan latar belakang mereka serta tipologi kontruksi individu yang memperngaruhi. peneliti mendapatkan mengorek keterangan dari bapak Mahsun beliau bercerita:

"Sebelum budidaya ini menjamur, saya pribadi keteteran dengan urusan ibadah. fikiran saya hanya fokus untuk mengenyangkan isi perut dan memenuhi kebutuhan seharihari. saya kerja serabutan. asalkan ada yang bisa saya kerjakan ya saya kerjakan. adapun urasan salat saya sering bolong dan puasa pun juga demikian. waktu lebih banyak saya gunakan untuk mencari uang. maklum ekonomi saya waktu itu masih pas-pasan. kini setelah melakukan budidaya saya lebih memiliki waktu. urusan ekonomi yang selalu memusingkan sudah tertangani. sayapun bersyukur dapat beribadah dengan baik" ${ }^{15}$

Senada dengan keterangan bapak Mahsun adalah bapak Samuin. beliau menjelaskan:

"Budidiya ini disamping membawa berkah juga meningkatkan ibadah saya dan keluarga. dulu kami tidak begitu memetingkan urusan ibadah, kini setelah kami cukup dari segi ekonomi, kami lebih tekun dalam ibadah. salat yang semula masih bolong-bolong kini sudah tidak lagi. puasa yang juga masih bolong-bolong kini sudah penuh dan dulu yang mana kami menerima zakat dari orang-orang sekarang kamilah yang memberikan zakat". ${ }^{16}$

Berdasarkan paparan dari Bapak Mahsun dan Bapak samuin dapat dipahami bahwa latar belakang ekonomi mempengaruhi kualitas religius seseorang. ibadah tidak lebih penting daripada mengumpulkan pundi-pundi uang guna mencukupi kebutuhan sehari-hari. pengabain terhadap agama pada dasarnya adalah sebuah kesalahan. hadirnya budidaya karang hijau telah memicu masyarakat setempat yang semula tidak memiliki waktu beribadah menjadi mempunyai waktu yang cukup untuk beribadah. masyarakat juga bisa lebih fokus dalam mengerjakan ibadah rutinitas sehari-hari. Hal tersebut dikuatkan oleh pemaparan Rudiyanto:

"budidaya itu membawa berkah. bukan hanya ekonomi yang cukup, ibadah saya lebih baik. kerja karang hijau itu mudah, Cuma datang pada waktu malam. kami banyak memiliki waktu luang. akhirnya bisa jamaah di masjid, bisa bersedekah, bisa menjadi donatur dan penggerak kegiatan keagamaan. saya pribadi dan istri juga sudah daftar haji. dulu saya ingin

${ }^{14}$ Samu'in Wawancara (Bengkel Perahu) 23 April 2019.
${ }^{15}$ Mahsun, Wawancara ( rumah) Tanggal 27 April 2019.

${ }^{16}$ Samu'in Wawancara (Bengkel Perahu) 23 April 2019. 
Leadership: Jurnal mahasiswa manajemen pendidikan Islam

ISSN (P): 2721-7108, ISSN (E): 2715-0399

Vol. 2 No. 2 bulan Juni 2021

tidak pontang- panting mencari rizki hinngga meninggalkan ibadah, sekarang al- hamdulillah bisa lebih baik". ${ }^{17}$

Budidaya kerang yang menitik beratkan pada pekerjaan menangkap ikan di tengah malam memberikan banyak kesempatan pada masyarakat untuk beribadah dan berkecimpung dalam kegiatan-kegiatan sosial keagamaan. kualitas religius masyarakat semakin meningkat seiring meningkatnya ekonomi seperti dapat salat berjamaah dan menjadi motor dalam membatu masyarakat sekitar yang kurang mampu. hal ini membuktikan bahwa agama dan ekonomi perlu berjalan beriringan agar dapat mendorong dan memotivasi seseorang menjadi pribadi baik yang dapat memberikan manfaat kepada lingkungan sekitarnya.

4. Manfaat Budidaya dari segi kesehatan

Budidaya karang hijau di desa campurejo yang meningkatkan ekonomi masyarakat juga memberikan efek domino atas peningkatan kualitas kesehatan masyarakat. hal ini sebagaimana dijelaskan oleh Karjo:

"Kami tentu memikirkan kesehatan. namun untuk mendapatkan akses kesehatan yang baik kami kesulitan. kami masih sering melakukan pengobatan secara tradisional dengan memanfaatkan tumbuhan-tumbuhan dan pijet. hanya ketika benar-benar sakit kami baru berani periksa ke dokter. setelah budidaya ini kami tanpa ragu lagi periksa tanpa dipusingkan biaya"18. $^{\prime 18}$ Bapak Romaji juga menambahkan:

"Makan yang enak-enak kami tidak mampu. kami makan seadanya. kadang kami juga ngutang untuk mencukupi kebutuhan kami. kini setelah budidaya kami bisa makan daging setiap hari dan buah-buahan. asupan bergizi bisa kami beli dan kami konsumsi". ${ }^{19}$

Kehadiaran budidaya telah sangat dirasakan dampak positifnya bagi masyarakat Campurejo khusunya di bidang kesehatan. Masyarakat dapat mendapatkan pola kesehatan lebih baik dengan mengonsumsi makanan dan minuman bergizi serta mendapatkan akses kesehatan yang lebih layak. Biaya pengobatan dan pemenuhan nutrisi tubuh yang semula dirasa berat kini tanpa pusing lagi bisa terselesaikan. Hal ini menjadi bukti bahwa ekonomi telah menciptakan efek berantai atas aspek-aspek kehidupan manusia. lebih lagi dalam masalah kesehatan. tingkat kepedulian terhadap kesehatan semakin tinggi bekat adanya kemapanan ekonomi sehingga dapat meningkatkan kesejahteraan masyarakat itu sendiri.

5. Manfaat Budidaya dari segi perkembangan polah asuh anak

Pengasuhan anak bertempu pada kepedulian dan perhatian orang tua atas anaknya. semakin tinggi tingkat kepeduliaan oprang tua maka akan semakin meningkatkan pola tumbuh kembang anak. hal ini dapat tercermin dari gambaran keterangan yang disampaikan oleh bapak Mahsun:

"Dulu cita-cita saya adalah dapat mengkuliahkan anak saya. tapi dulu sangat dirasa tidak mungkin, mengingat ekonomi kami yang pas-pasan. kini anak kami telah menempuh jenjang perkuliahan di universitas negeri ternama Surabaya. kami juga memberikan pendidikan dan kesehatan secara maksimal kepada anak kami". ${ }^{20}$

bapak rudi juga menambahkan:

\footnotetext{
${ }^{17}$ Rudiyanto, Wawancara, (Rumah) 04 Mei 2019

${ }^{18}$ Karjo, Wawancara (TPI) Tanggal 04 Mei 2019

${ }^{19}$ Romaji, Wawancara (Pasar Desa Campurejo) Tempat Pelelangan Ikan (TPI) 25 April 2019

${ }^{20}$ Mahsun, Wawancara ( rumah) Tanggal 27 April 2019.
} 
Leadership: Jurnal mahasiswa manajemen pendidikan Islam

ISSN (P): 2721-7108, ISSN (E): 2715-0399

Vol. 2 No. 2 bulan Juni 2021

"Anak kami sekarang lebih banyak memiliki waktu bersama keluarga. saya meninggalkannya di waktu ia telah tidur untuk menuju karang hijau saya dan istri lebih mempunyai banyak waktu mengawasi anak kami. kebutuhannya pun secara finansial bisa kami penuhi"

Pola asuh anak masyarakat campurejo yang berkecimpung dalam budidaya karang hijau bisa dikategorikan baik. sebab hak-hak anak dapat terpenuhi secara maksimal dikarenakan tersedianya finansial yang memadai. di samping itu kehadiran keluarga dalam mengawasi anak secara langsung dampak berdampak positif terhadap perkembangan anak. masyarakat campurejo juga bisa memberikan jenjang pendidikan perkuliahan pada anakanaknya.

Budidaya Kerang hijau membawa sederet dampak positif bagi para pelaku usaha di bidang hal ini. apabila dirumuskan dan diintegrasikan dengan konsep maqasid syariah tentu hal ini akan sejalan dan melengkapi. untuk lebih jauh mengupas dan mengkaji budidaya Kerang terkait proses dan imbasnya dengan ditinjau dari maqasid syariah maka akan diulas sebagaimana berikut:

a. Intergrasi Manajemen Perekonomian dengan Budidaya Kerang Hijau

Dengan pengelolahan sistem manajemen yang baik maka hasil yang akan di peroleh akan maksimal hal ini di buktikan dengan beberapa hasil pemaparan wawancara dengan beberapa data dari informan yang kami dapatkan. Dengan melaksanakan teori manajemen yang baik seperti George R. Terry yang menjelaskan fungsi manajemen yang terdiri dari: Planning, Organizing, Actuating, Controlling. ${ }^{21}$

Dalam melaksanakan Planing masyarakat pembudidaya benar-benar melakukan perencaan dengan baik, baik dari segi modal, pembuatan, pemberdayaan sampai dengan membuka lapangan pekerjaan bagi masyarakat sekitar dalam pengelolahanya.

Dalam Organizing masyarakat pembudidaya mampu mengorganisir, mulai mngorganisir penjual kerang, tengkulak, termasuk juga karyawan yang mengupas kerang semua terorganisir dengan baik.

Dalam Actuating masyarakat pembudidaya mampu melakukan catatan-catatan mulai dari peminjaman permodalan, pendapatan sampai dengan penyimpanan hasil uang, hal ini di buktikan dengan argument beberapa informan yang gaya hidupnya jauh lebih mneingkat baik dari segi kebutuhan primer, sekunder maupun tersier.

Dalam segi Controling masyarakat pembudidaya mampu mengontrol perkembangan kerang terutama dalam segi harga, karena masyarakat sepakat dalam pengajuan harga masyarakat tidak boleh menjual di bawah harga kesepakatan ini yang membuat perekonomian stabil karena tidak saling bersaing dengan antar pembudidaya.

b. Relevansi Maqașid Syariah Dengan Hasil Budidaya Kerang Hijau

Budidaya Kerang hijau adalah usaha rakyat yang dilakukan masyarakat Campurejo dengan memanfaatkan laut guna menangkap dan mengembang biakkan Kerang, ikan dan hasil laut lainnya. Keuntungan dari budidaya ini dapat dirasakan baik secara individu atau komunitas dan dapat memberikan dampak positif terhadap peningkatan sendi-sendi kehidupan masyarakat campurejo. Guna lebih detail mengetahui hasil budidaya Kerang hijau yang dikolaborakiskan dengan maqasid syariah akan diulas sebagaimana berikut:

${ }^{21}$ Malayu S.P. Hasibuan, Manajemen Dasar, Pengertian, Dan Masalah, (Jakarta: Bumi Aksara, 2009). hlm. 21. 
Leadership: Jurnal mahasiswa manajemen pendidikan Islam

ISSN (P): 2721-7108, ISSN (E): 2715-0399

Vol. 2 No. 2 bulan Juni 2021

1) Hasil budidaya Kerang hijau dalam koridor kebutuhan

a) Dlaruri (primer)

Hasil budidaya Kerang laut telah mencukupi kebutuhan sehari-hari dari masyarakat campurerjo. kebutuhan pokok terkait apa yang dibutuhkan dalam kehidupan baik diri sendiri atau keluarga telah tercukupi sepertei kebutuhan makanan, minuman, tempat tinggal serta hak-hak yang harus dipenuhi atas suami kepada aank dan istrinya. untuk mengetahui lebih jauh relevansi Maqașid Syariah mengenai hal ini akan dikupas oleh peneliti dalam sub tersendiri.

b) Haji (sekunder)

Kebutuhan primer dalam koridor Maqașid Syariah berfungsi sebagai media guna meningkatkan hal dlaruri (primer). Selaras dengan devinisi hajiyat yaitu hal-hal yang dimaksudkan untuk mempermudah dan meminimalisir kesulitan dan kesusahan seperti syariat jual beli dan sewa menyewa maka barang tentu hakikat budidaya Kerang hijau termasuk bagian dari hajiyat, karena berfungsi sebagai media pemenuhan atas hal-hal pokok yang dibutuhkan dalam kehidupan. Di samping itu, kebutuhan manusia atas hal-hal sekunder dapat dipenuhi melalui profit budidaya Kerang hijau.

c) Tahsini (tersier)

Pada dasarnya tahsini adalah kemaslahatan yang memiliki nilai meningkatkan dan memperbaiki kualitas kehidupan. kemaslahatan tahsini cenderung lebih mengutamakan etika dan sarana dalam berbagai aspek hukumnya. berdasarkan hal demikian dapat dipahami bahwa budidaya Kerang hijau ditinjau dari segi dampak positifnya bukan hanya memenuhi kebutuhan dlaruri, haji saja. namun juga dapat memberi nilai lebih dalam hal tashsini.

c. Relevansi Hasil Budidaya Dengan Lima Hal Pokok MaqașidSyariah

1) Hifdzul mal

Budidaya Kerang hijau mampu meningkatkan taraf ekonomi masyarakat Campurejo. kata hifdzu tidak diartikan hanya sebatas memberikan proteksi namun juga dimaksudkan untuk meningkatkan finansial seseorang. Dengan meningkatnya finansial, masyarakat campurejo tidak akan kesulitan dalam memenuji hajat hidup mereka. Islam mewajibkan zakat, menganjurkan sedekah, hibah dan wakaf menunjukkan bahwa manusia didorong untuk menguatkan finansialnya agar supaya mampu membantu dan menolong yang lain. sementara disisi lain islam menyalurkan dana zakat dan sedekah kepada fakir miskin menjadi bukti bahwa islam tidak menginginkan pemeluknya dirundung kelaparan

2) Hifdzu akl

Hasil budidaya Kerang hijau membawa berkah bagi masyarakat campurejo. bukan hanya di bidang ekonomi tapi juga di peningkatan pendidikan dan pengetahuan. para pengusaha mendapatkan wawasan bagaimana cara meningkatkan ekonomi melalui budidaya Kerang hijau. semula pengetahuan ini tidak begitu dikenal. namun setalah Kerang hijau benar-benar menghasilkan profit yang menguntungkan, banyak orang mulai mempelajari bagaiamana tatacara dan proses budidaya Kerang hijau ini. tidak luput masyarakat Campurejo yang ekonominya waktu itu kurang begitu baik.

3) Hifdzu nafs

Melindungi nafs (badan) bukan hanya dimaksudkan menjaga agar tidak dilukai tapi juga bagaimana badan itu bisa berkembang maksimal. hal ini tentu dengan melakukan pola hidup yang sehat. Pola demikian dapat ditempuh dengan cara mengonsumsi 
Leadership: Jurnal mahasiswa manajemen pendidikan Islam

ISSN (P): 2721-7108, ISSN (E): 2715-0399

Vol. 2 No. 2 bulan Juni 2021

makanan dan minuman yang bergizi. apabila tubuh terserang penyakit maka harus segera ditangani dan diobati. profit dari budidaya Kerang hijau menjadikan seseorang memiliki peluang guna memperbaiki pola makan dan kesehatannya.

4) Hifdzu din

Menjaga agama artinya adalah dengan menjalankan perintah agama seperti salat, puasa, sakat dengan istiqamah. Peran budidaya Kerang hijau dalam meningkatkan religiusitas seseorang adalah dengan memberinya waktu luang dalam menjalanka ibadah. Usaha Kerang hijau yang dilakukan tengah malam hingga subuh memberikan waktu yang luang bagi masyarakat untuk menjalankan ibadah salat lima waktu. Hal berbeda apabila seseorang harus banting tulang bekerja keras karena belum terpenuhinya kebutuhan sehari-hari sedikit banyak akan lalai dengan salatnya.

5) Hifdzu nasl

Aplikasi menjaga keturunan dalam pola kehidupan adalah dengan menumbuh kembangkan anak dengan maksimal. Perkembangan anak sangat penting karena anak adalah penyambung keturunan sekaligus menjadi investasi di alam akhirat. Memelihara anak adalah dengan memenuhi hak-haknya. jika ditinjau dari keluarga pengusaha Kerang hijau dapat tergambarkan bahwa anak-anak dari mereka telah menerima pendididkan yang layak.

\section{KESIMPULAN}

Proses pembudidayaan kerang hijau di Desa Campurejo terbilang sangat mudah dan efektif karena masyarakat menggunakan pemanfaat bambu yang berada di alam sekitar kecuali yang tidak punya bisa membeli bambu pada masyarakat sekitar, proses budidaya kerang hijau ini melibatkan beberapa pihak tidak hanya dengan pemilik dan pembeli tapi juga dengan masyarkat sekitar, mulai dari proses pembuatan, perawatan, pembuatan alat transportasi (perahu), pengambilan sampai dengan pengupasan kerang semua di proses oleh masyarkat sekitar dan mencipatakan lapangan pekerjaan bagi bnyak kalangan termasuk para tukang yang membuat perahu, bengkel mesin perahu sehingga rantai kegiatan perekonomian warga sekitar dengan adanya budidaya kerang hijau sangat terbantu untuk memenuhi kehidupan sehari-harinya.

Budidaya kerang hijau memiliki manfaat yang besar bagi masyarakat Campurejo. Profit besar yang diperoleh melalui budidaya ini meningkatkan kesejahteraan ekonomi yang sekaligus memiliki efek berantai terhadap peningkatan kesehatan, pendidikan, religiusitas dan pola asuh anak. Ditinjau dari maqasid syariah, kedudukan budidaya kerang laut adalah sebagai wasilah atau media terwujudnya tujuan syariah islam dalam mensejahterakan umatnya. Budidaya kerang laut tidak bertentangan prinsip-prinsip syariah bahkan diakomodir sebagai bagian syariah itu sendiri. Menimbang media budidaya merupakan usaha pemenuhan hajat hidup masyarakat Campurejo dalam kesehariannya bahkan manfaatnya berlaku secara luas

Budidaya kerang laut dalam meningkatkan taraf ekonomi masyarakat meningkatkan unsur-unsur dlaruri (primer), haji (sekunder), tahsini (tersier) yang menjadi acuan dalam maqasid syariah. Di samping itu manfaat budidaya kerang hijau dapat dirasakan oleh khalayak umum dengan terbukanya lapangan pekerjaan. Secara spesifik kematangan finansial (hifdzul mal) memiliki efek domino atas meningkatnya kesejateraan dalam segi kesehatan (hifdzul nafs), pendidikan (hifdzul akl), religiusitas (hifdzul din) dan pola asuh anak (hifdzu nasl). Dari 
Leadership: Jurnal mahasiswa manajemen pendidikan Islam

ISSN (P): 2721-7108, ISSN (E): 2715-0399

Vol. 2 No. 2 bulan Juni 2021

sini dapat diketahui bahwa maslahat dalam budidaya kerang sejatinya adalah maslahat yang diinginkan oleh pencipta syariat guna menjadikan umatnya lebih sejahtara.

\section{REFERENSI}

Adhinda Dewi Agustine dkk. Pengembangan Sektor Kelautan Dan Perikanan Untuk Meningkatkan Pendapatan Asli Daerah. Jurnal Administrasi Publik (JAP), Vol. 2, No.2. 2014

Ali, Rama, dan Makhlan. Pembangunan Ekonomi Dalam Tinjauan Maqashid Syari'ah. Dialog Vol. 36, No.1. 2013.

Burhan Bugin, Penelitian Kualitatif Komunikasi Ekonomi, Kebijakan Public dan Ilmu Sosial Lainnya. Jakarta: Kanacan Media Group, 2007.

Femy M. G, Tulusan dan Very Y. Londa Peningkatan Pembagunan Ekonomi Melaluhi Pemberdayaan Desa. (Jurnal LPPM Bidang EkoSosBudKum Volume 1 Nomer 1 Tahun 2014) (Fakultas Ilmu Sosial dan Pemerintahan, Universitas Sam Ratulangi).

Hartoyo dan Noorma Bunga Aniri, Analisis Tingkat Kesejateraan Keluarga Pembudidaya Ikan dan Non pembudidaya Ikan di kabupaten Bogor, Jurnal Ilm. Kel dan Kons, 1 ( Januari, 2010)

Malayu S.P. Hasibuan, Manajemen Dasar, Pengertian, Dan Masalah, (Jakarta: Bumi Aksara, 2009).

Sugiyono, Metode Penelitian Kuantitatif Kualitatif Dan R\&D (Bandung: Alfabeta, 2006)

Zaki Fuad Chalil, Pemerataan Distribusi Kekayaan Dalam Ekonomi Islam, Jakarta: Erlangga ,2009. 